https://doi.org/10.18485/bogoljub_stankovic.2018.ch8

81'243:316.722

$371.1:: 811.161 .1(497.2)$

ДИМИТРИНА ЛЕСНЕВСКАЯ*

Университет национального и мирового хозяйства

Факультет международной экономики и политики

\title{
МЕТОД КОНТРАСТИВНОГО ИЗУЧЕНИЯ МОДЕЛЕЙ РЕЧЕВОГО ПОВЕДЕНИЯ В ОБУЧЕНИИ РУССКОМУ ЯЗЫКУ КАК ИНОСТРАННОМУ
}

В статье предлагается организация учебного материала в практике преподавания русского языка как иностранного в болгарской аудитории при обучении эпистолярному дискурсу с позиции межкультурного подхода, предполагавшего реализацию равноправного диалога культур как механизма «мягкой силы». Теоретической основой этого нового подхода при обучении иностранному языку, в частности при обучении РКИ, является теория контрастивного лингвистического исследования на базе новой коммуникативной единицы - «модель речевого поведения», с применением полевого метода. Теория моделей речевого поведения и коммуникативно-прагматического поля являются теоретической базой дискурсивного обучения иностранным языкам с позиции равноправного диалога культур (иноязычной и родной), технология которого включает как обязательный элемент сопоставление изучаемого иноязычного материала с родным. В статье выделяются основные модели речевого поведения в рамках коммерческих писем на русском изучаемом и болгарском родном языках.

Ключевые слова: модель речевого поведения, коммуникативно-прагматическое поле, межкультурный подход, «мягкая сила», толерантность, межкультурная коммуникация, межкультурная коммуникативная компетенция, прагмалингвистическая компетенция, обучение РКИ, эпистолярный дискурс, коммерческие письма

\section{Dimitrina Lesnevska}

\section{CONTRASTIVE RESEARCH ON MODELS OF SPEECH BEHAVIOR IN TEACHING RUSSIAN AS A SECOND LANGUAGE}

In this article we propose organization of teaching materials in practice of teaching Russian as a second language to the Bulgarian audience. We focus on teaching epistolary discourse from the position of the intercultural approach, which presupposes realization of dialogue equality.

Key words: model of speech behavior, communicative-pragmatic field, intercultural approach, ?soft power?, tolerance, intercultural communication, intercultural communicative competence, pragmalinguisticcompetence, teaching Russian as a second language, epistolary discourse, business letters

\footnotetext{
*demetra3@gmail.com
} 
В сегодняшнем глобализованном мире учёт национальных особенностей и национального менталитета является одним из важнейших факторов успешной коммуникации на всех уровнях. Участниками межкультурной коммуникации (МК) являются реальные люди - носители определенных ценностей: национальных особенностей и национального менталитета. МК предполагает многоаспектное взаимодействие культурных форм. Партнерство предполагает «мягкое», ненасильственное взаимовлияние, учет «чужих» культур, личностного фактора. Так, «мягкая сила» представляет собой необходимый компонент, способствующий развитию плодотворных контактов. «Культурные модуляторы», являющиеся параметрами «ценностных» вторжений в условно чужое социокультурное пространство, исследуются в рамках культурологии, лингвокультурологии, философии культуры, в частности в разработках МГИМО (У). Философско-культурологическая школа МГИМО-У исследует историю и теорию культуры, философию культуры, культурологические особенности МК,опираясь на феноменологические описания, фиксирующие основы «своей» и «чужой» культуры. (Шестопал, Силантьева 2012).

Впервые термин «мягкая сила» (англ. soft power) употребил американский политолог, профессор Гарвардского университета США Джозеф Най в 1990 г., когда окончилась холодная война. В настоящее время концепт «мягкая сила» исследуется в лингво-культурологических, социологических, политических и философских ракурсах.

В международных отношениях «мягкой силой» является язык и культура, применяются гуманитарные методы и технологии «мягкой», культурной дипломатии (Горлова, Бычкова 2015). «Мягкая сила» предусматривает продвижение своих интересов и подходов путем убеждения и привлечения симпатий с опорой на возможности гражданского общества. Так, китайский язык и культура стали важным ресурсом «мягкой силы» (Бояркина 2014).

По мнению ректора МГИмО Анатолия Торкунова:«Не империя, а культурное продвижение; не пушки, не импорт политических режимов, а экспорт образования и культуры помогут создать благоприятные условия для российских товаров, услуг и идей» (Торкунов 2012). Стратегия «мягкой силы» предполагает экспорт образования, продвижение языка и распространение национальных культурных ценностей. Эффективность высшего образования как инструмента «мягкой силы» можно оценить только в долгосрочной перспективе.

Образование играет роль инновационного внешнеполитического инструмента «мягкой силы», причем большое значение в процессе воспитания толерантности к чужим культурным ценностям имеет обучение иностранным языкам. Так, в глобализированном мире востре- 
бовано поликультурное образование, способствующее формированию межкультурной компетенции. Для формирования межкультурной компетенции необходимо осознать и оценить собственную и иную культуру. Идея межкультурности в контексте образования предполагает применение межкультурного подхода к обучению иностранному языку как механизма «мягкой силы». Формирование межкультурной коммуникативной компетенции приводит к осуществлению диалога равноправных культур - иноязычной и родной.

На сегодняшнем этапе развития лингводидактики обучение языку и культуре рассматривается как инструмент «мягкой силы» (Тарева 2016). «Мягкая сила» релизуется с помощью культуры, дипломатии, науки, образования. Установлена неделимость изучения иностранного языка с ознакомлением с культурой страны изучаемого языка. Если изучать только культуру иной страны, возникают условия образования этноцентризма. Поэтому в учебной ситуации необходимо обеспечить полное равноправие культурных ценностей изучаемого и родного языков. Применяя межкультурный подход к обучению иностранному языку, в учебном процессе нужно достичь признания фактов двух культур как полноценных и равноправных. Целью обучения иностранному языку является формирование межкультурной коммуникативной компетенции. Межкультурный подход действует в соответствии с механизмом «мягкой силы», реализуя диалог культур и формирование подлинной толерантности как качества личности.

При современном коммуникативном межкультурном подходе к преподаванию иностранных языков, основанном на теоретических постулатах коммуникативной стилистики и прагмалингвистики, объектом обучения является дискурс - целостное речевое произведение, включающее в себя текст и экстралингвистические факторы. Единицей дискурса является речевой акт, реализующийся коммуникантами - адресантом и адресатом в рамках его составляющих: локуции, иллокуции и перлокуции. Дискурсивное обучение направлено на формирование прагмалингвистической компетенции как основного компонента межкультурной коммуникативной компетенции в русле равноправного диалога родной и иноязычной культур. Прагмалингвиситчесакя компетенция представляет собой способность ориентироваться в коммуникативно-прагматическом пространстве и правильно использовать правила речевого поведения в конкретной ситуации общения, адекватно совершать коммуникативный акт (совокупность речевых актов). В учебном процессе для реализации равноправного диалога необходимо сопоставление языковых форм изучаемого и родного языков.

В учебном процессе дискурсивного обучения иностранным языкам, направленном на реализацию равноправного диалога культур как 
механизма «мягкой силы», возможно продуктивно использовать базовые единицы коммуникативного лингво-прагматического анализа - модели речевого поведения и коммуникативно-прагматическое поле. Модель речевого поведения (МРП), включающая в себя вербальные и невербальные действия, служит основой в контрастивных лингвистических исследованиях (Гладров, Которова 2015).

Понятие «коммуникативно-прагматическое поле», а также полевой метод исследования речевых актов разработаны проф. д.ф.н. Елизаветой Г. Которовой, представителем российской Томской лингвистичной школы, профессором в Зеленогурском у-тете (Польша) (Которова 2013). Полевой метод дает возможность определения структуры речевых актов как функционально-коммуникативного поля, имеющего взаимосвязанные элементы, в составе которых самым важным доминирующим элементом является иллокуция (коммуникативная цель). Применение понятия «поле» для анализа форм реализации МРП является существенным вкладом в развитие теории речевых актов и их контрастивном исследовании в различных языках, так как полевая модель дает возможность выявить системные отношения элементов, их парадигматические и синтагматические отношения. Коммуникативно-прагматическое поле - совокупность иллокутивной силы МРП, объединяющая весь инвентарь разнообразных грамматических, лексических, словообразовательных, синтаксических и др. средств, выражающих определенную иллокутивную цель.

Полевой метод применяют в своих исследованиях Юлия М. Сулейманова, анализируя перформативный глагол как средство экспликации ассертивной интенции (Сулейманова 2010), Елена А. Филимонова в своей разработке о комиссивах в сопоставительном плане английского и русского языков (Филимонова 2003), а также Галия Р. Шамьенова в своей работе о категории вежливости (Шамьенова 2000). Принцип вежливости как особой коммуникативно-прагматической категории находит яркое выражение в эпистолярии.

Эпистолярный дискурс как особая форма межличностной письменной коммуникации и специфический стилистически синкретичный тип дискурса является эффективным учебным материалом при обучении РКИ в болгарской аудитории. Эпистолярий представляет собой совокупность писем от греч. epistole, лат. epistola - письмо, послание. Одним из главных свойств эпистолярия является ярко выраженный антропоцентризм, при котором эпистолярная языковая личность (автор - адресант-отправитель эпистолярных текстов) составляет «вербальное ядро» эпистолярного типа дискурса. Коммерческие письма (КП) - подвид деловых писем, документы хозяйственно-правового значения, осуществляющие письменную коммуникацию в целях осуществления 
торговой сделки. Деловые письма, в частности КП, являются ценным учебным материалом при преподавании профессионально-делового РКИ в болгарской аудитории (Лесневска 2015). При учебном анализе коммерческой корреспонденции на занятиях по РКИ в болгарской аудитории выделяем модели речевого поведения КП на русском и болгарском языках, применяя метод коммуникативно-прагматического поля. Так, эпистолярный дискурс рассматривается в учебных целях в русле коммуникативно-прагматического, межкультурного подхода. В основе коммуникативного обучения составлению коммерческих писем при обучении РКИ лежат теория перформативности, прагмалингвистика, теория речевых актов, контрастивное изучение моделей речевого поведения, метод коммуникативно-прагматического поля.

Термин «перформатив» появился в теории речевых актов Дж. Остина и Дж. Серля. Речевой акт - центральное понятие прагмалингвистики, означающее речевое действие - высказывание в ситуации непосредственного общения с адресатом. Перформатив (глагол в перформативном употреблении, перформативное высказывание, перформативное предложение) эквивалентен действию или поступку - т.е. перформатив - это слово и действие одновременно (лат. performo - geйствую; англ. perform - исполнять, выполнять, играть роль, преgставлять). Так, перформативное действие осуществляется самим речевым актом. Различаются прямые перформативы (рус. Советую Вам посетить эту выставку./ болг. Съветвам Bu ga посетите тази изложба.) и косвенные перформативы (вежливые просьбы) типа рус. Вы не могли бы посетить эту выставку. / болг. Дали бихте могли gа посетите тази изложба? («замаскированный» риторический вопрос).

Понятие иллокуции в эпистолярии связано с понятием интенции, цели отправителя письма (адресанта) воздействовать на реципиента (адресата) с помощью письменной речи. Прагмалингвистические особенности КП определяются спецификой эпистолярного дискурса: особой формой речевого общения; наличием адресанта, адресата, вокатива; четко выраженной интенцией адресанта, коммуникативными цепочками писем и писем-ответов. Эпистолярная коммуникация представляет собой особый диалогизированный монолог в письменной форме (Лесневска 2016а).

Набор интенций и речевых актов в КП относятся к пресуппозитивным знаниям (пресуппозиции определенного вида (поджанра КП). Адресант выбирает соответственный вид КП для реализации своих интенций (конкретного иллокутивного акта), а адресат воспринимает данный текст в соответствии с подобными текстами. Так, к пресуппозиции определенного вида КП относится его структура, иллокуция, преобладающий речевой акт. Речевой акт состоит из локуции (высказывание), 
иллокуции (коммуникативная цель) и перлокуции (результат высказывания, воздействие на адресата). Выделяются следующие виды иллокутивных целей: ассертивная, комиссивная, директивная, декларативная, экспрессивная. К типам речевых актов относятся ассертивы (сообщение, подтверждение), комиссивы (обещания), директивы (просьба, совет, приглашение), декларативы (объявления), экспрессивы (благодарность, извинение, сожаление) (Лесневска 2016б).

Выделяем следующие модели речевого поведения русских и болгарских коммерческих писем: сообщение (набор ассертивов); обещание (набор комиссивов); просьба, предложение, приглашение, совет, предупреждение, напоминание, требование, запрет, разрешение (набор директивов); подтверждение, отказ, декларация, объявления (набор декларативов); благодарность, извинение, поздравление, прощание, пожелание, сожаление, надежда (набор экспрессивов):

1) СООБЩЕНИЕ (НАБОР АССЕРТИВОВ) - болг. съобщаваме, увеgомяваме, известяваме/ рус. сообщаем, уведомляем, ставим в известность. Ядро ассертивной МРП - болг. глагол съобщавам в форме мн.ч. 1 лица-съобщаваме; рус. увеgомляю - увеgомляем.

МРП сообщения оформляют уведомительные письма: письма-извещения, письма-подтверждения.

2) ОБЕЩАНИЕ (НАБОР КОМИССИВОВ) - рус. гарантируем, обязуемся, заверяем / болг. гарантираме, заgблжаваме се, заверяваме.

Напр.: болг. Безусловно се ангажираме gа...; Заgължаваме се gа...; Ние с настоящето поемаме неотменимо и безусловно заgғлжение...; Гарантираме слеgното ниво на....; Гарантираме, ие...; Гарантираме тайната на съобщението/ рус. Принимаем обязательство; Обязуемся...; Гарантируем....

Ядро комиссивной МРП - болг. глагол гарантирам, заgължавам се в форме 1 л. мн.ч.: гарантираме, заgғлжаваме се / рус. гл. в мн.ч. гарантируем, обязуемся.

Периферия комиссивной МРП состоит из устойчивых глагольноименных словосочетаний типа болг. поемаме аgължение, ние сме готови ga; ще направим всиико възмонно gа, имаме голямо желание gа - 1 л.мн.ч./ рус. принимаем обязательство, мы готовы с делать все возмонное и gр.

МРП обещания оформляют креативные письма, гарантийные письма.

3) ПРОСЬБА, ПРЕДЛОЖЕНИЕ, ПРИГЛАШЕНИЕ, СОВЕТ, ПРЕДУПРЕЖДЕНИЕ, НАПОМИНАНИЕ, ТРЕБОВАНИЕ, ЗАПРЕТ, РАЗРЕШЕНИЕ (НАБОР ДИРЕКТИВОВ) - рус. просим, прошу, преgлагаем, преgлагаю, приглашаем, советуем, преgупреняаем, напоминаем, требуем, разрешаем, запрещаем / болг. молим, моля, преgлагаме, преgлагам, каним, съветваме, преgупрежgаваме, напомняме, изискваме, разрешаваме, забраняваме. 
В ядро директивных МРП входят глаголы: болг. моля, каня, съветвам, напомням и др. / рус. прошу, приглашаю, советую, напоминаю и gр.

МРП просьбы, предложения, напоминания и т.п. оформляют следующие коммерческие креативные письма: письмо-запрос, свободная офферта, презентационные (имиджевые) письма, письмо-приглашение, напоминательные письма.

4) ПОДТВЕРЖДЕНИЕ, ОТКАЗ, РЕКЛАМАЦИЯ (НАБОР ДЕКЛАРАТИВОВ) - рус. о ообряем, по этвержяаем, объявляем, осужgаем, принимаем, отказьваемся, настаиваю, настаиваем / болг. оgобряваме, потвържgаваме, обявяваме, осъжзаме, приемаме, отказваме се, настоявам, настояваме.

МРП коррекции оформляют следующие коммерческие письма: письмо-подтверждение, письмо-отказ, рекламации.

5) Благодарность, извинение, поздравление, прощание, пожелание, сожаление, надежда (набор экспрессивов): рус. благоgарим, извиняемся, поздравляем, желаем, сожалеем, надеемся / болг. благоgарим, извяваме се, поздравяваме, нелаем, съжаляваме, наяяваме се.

МРП речевых ритуалов оформляет следующие коммерческие эмотивные письма: письмо-благодарность, письмо-извинение, письмопоздравление, письмо-сожаление.

Характерной особенностью КП является синонимия МРП. При преподавании бизнес-русского языка в болгарской аудитории обращается внимание на наличие многообразных синонимических перформативных высказываний, репрезентирующих определенную МРП в русских и болгарских КП.

Напр., синонимия МРП просьбы в письме-запросе - рус. Просим Вас преgоставить gанные...; Просим рассмотреть возможность...; Желательно было бы выслать...; Обращаемся к Вам с просьбой отправить нам...; Буgем весьма признательны/ благоgарны, если... - болг. Молим gа ни изпратите информаиия...; Молим направете ни оферта...; Бихме Ви били много заgължени, ако...; Бихте ли били така любезни gа ни изпартите... .

Другой характерной особенностью КП является высокая частотность косвенных перформативов в составе МРП коммерческих писем. Особое внимание обращается на употребление косвенных перформативных высказываний со смягченной иллокуцией («мягкой силой»), оформленных при помощи условных конструкций:

Напр.: рус. Не могли бы Вы нам послать... - болг. Бихте Ви помолили gа ни изпратите... Перформативы в составе МРП в рамках КП являются стилевыми маркерами речевой этикетности, вежливости, реализующими «мягкую силу» в текстах КП. 
Особый интерес вызывают письма-экспрессивы с этикетными формулами благодарности, извинения, пожелания, сожаления. Так письмаэкспрессивы можно считать инструментами «мягкой силы».

Сравн. в разновидности «ПИСЬМО-ИЗВИНЕНИЕ» - МРП извинения рус. Примите наши извинения за...; Приносим свои глубокие извинения за то, ито...; Мы искренне сожалеем, ито...; Мы хотели бы извиниться переg Вами за ... - болг. Трябва gа се извиним за...; Молим gа приемете нашите извинения за...; Молим приемете нашите извинения за...; Съжаляваме, ие..,; Много съжаляваме, ие...; Бихме желали gа Ви се извиним за... .

При обучении употреблению МРП в КП на занятиях РКИ разработан комплекс упражнений, среди которых ведущее место занимает учебный перевод. Для отработки практических навыков используются упражнения на составление русских КП на основе предварительно заданных параметров.

Подытоживая изложенное, следует отметить, что употребление перформативов в рамках МРП в качестве стилевых маркеров характерно как для эпистолярных письменных деловых текстов, так и для устной деловой речи, в частности, для деловых разговоров по телефону.

Необходимо иметь ввиду, что устная профессиональная деловая речь отличается разговорными признаками. В то время, как для коммерческих писем характерны сложные предложения, в профессиональной устной деловой речи преобладают простые предложения.

Стилевое разграничение письменной и устной форм межкультурного профессионально-делового дискурса учитывается при преподавании РКИ в болгарской аудитории. Так, на занятиях РКИ проводятся сравнение и сопоставление текстов КП и телефонного разговора на одну и ту же тему, например, на тему рекламаций.

Интересно сопоставление МРП коммерческих писем и МРП телефонного делового разговора.

Теория МРП и коммуникативно-прагматического поля является, на наш взгляд, удачной и востребованной базой осуществления межкультурности в образовании, как инструменте «мягкой силы», при реализации межкультурного подхода к обучению иностранным языкам, в частности при обучении эпистолярному дискурсу в рамках преподавания РКИ в болгарской аудитории. Для воспитания толерантности и формирование межкультурной коммуникативной компетенции в учебном процессе преподавания бизнес-русского языка (коммерческая корреспонденция) необходимо сопоставление русских и болгарских наборов МРП в рамках их коммуникативно-прагматических полей с разграничением ядра и периферии. 


\section{Цитирана литература}

Бояркина, А.В. «Язык и культура Китая как эффективные инструменты 'мягкой силы' в реализации внешней политики КНР». Теория и практика общественного развития 12, 2014: 115-118.

Гладров, В., Которова, Е.Г. «Контрастивное изучение моделей речевого поведения». Жанры речи 2 (12), 2015: 27-39.

Горлова, И.И., Бычкова, О.И. «Культура как 'мягкая сила': инструменты и точки положения». Теория и практика общественного развития 18, 2015: 268-272.

Которова, Е.Г. «Коммуникативно-прагматическое поле как метод комплексного описания способов реализации речевых актов». ТГПУ, Томский журнал лингвистики и антропологии 1(1), 2013: 58-67.

Лесневска, Д.С. «Обучение профессионально-деловому общению в теории и практике преподавания РКИ в болгарских нефилологических вузах». Болгарская русистика 1-2, 2015: 88-98.

Лесневска, Д.С. «Прагмалингвистические особенности эпистолярного дискурса в обучении РКИ в болгарской аудитории». Русский язык и культура в зеркале перевода. Москва: Макс Пресс, 2016а, 255-265.

Лесневска, Д.С. «Прагмалингвистические характеристики коммерческих писем на русском и болгарском языках в сопоставительном плане». Русский язык как инославянский, 2016б: 39-46.

Сулейманова, Ю.М. «Перформативный глагол как средство экспликации ассертивной интенции». Вестник ОГУ 11 (117), 2010: 90-93.

Тарева, Е.Г. «Обучение языку и культуре: инструмент 'мягкой силы'?». Вестник МГПУ. Серия «Филология. Теория языка. Языковое образование» 3 (23), 2016: 94-101.

Торкунов, А.В. «Образование как инструмент 'мякой силы' во внешней политике России». МГИМО-У, 4 (25), 2012: 85-93.

Филимонова, Е.А. Прототипическая картина комиссивов: На материале английского и русского языков. Дис...к.ф.н.. Уфа: Башкирский государственный университет, 2003.

Шамьенова, Г.Р. Принцип вежливости как особая коммуникативно-прагматическая категория в русском речевом общении. Дис...к.ф.н. Саратов: Саратовский государственный университет, 2000.

Шестопал, А.В., Силантьева, М.В. «Межкультурная коммуникация в свете современных модернизационных процессов: 'мягкая сила' культурных модуляторов». Вестник МГИМО-У 5 (26), 2012: 168-171. 
Димитрина Лесневска

\section{МЕТОД КОНТРАСТИВНОГ ПРОУЧАВАҢА МОДЕЛА КОМУНИКАЦИОНОГ ПОНАШАҢА У НАСТАВИ РУСКОГ ЈЕЗИКА КАО СТРАНОГ}

\section{Резиме}

У чланку се заснива организација наставног материјала у пракси предавања руског језика као страног у бугарској говорној и социокултурној средини при овладавању епистоларним дискурсом са позиција интеркултурног приступа, који претпоставља реализацију равноправног дијалога култура. Теоријски основ овог новог приступа јесте теорија контрастивног лингвистичког истраживања на основу нове комуникационе јединице - „модела комуникационог понашања", са применом комуникационо-прагматичког поља, што представља теоријску основу дискурзивне наставе страних језика. У чланку се идентификују основни модели комуникационог понашања у оквирима комерцијалних писама на руском као страном и бугарском као матерњем језику.

Кљуине речи: модел комуникационог понашања, комуникационо-прагматичко поље, интеркултурни приступ, толерантност, интеркултурна комуникација, интеркултурна комуникациона компетенција, прагмалингвистичка компетенција, настава руског језика као страног, епистоларни дискурс, комерцијална писма 